\title{
San Saba Mill Pond Park Survey, San Saba County, Texas
}

\section{Waynne Cox}

Center for Archaeological Research

Follow this and additional works at: https://scholarworks.sfasu.edu/ita

Part of the American Material Culture Commons, Archaeological Anthropology Commons, Environmental Studies Commons, Other American Studies Commons, Other Arts and Humanities Commons, Other History of Art, Architecture, and Archaeology Commons, and the United States History Commons

Tell us how this article helped you.

This Article is brought to you for free and open access by the Center for Regional Heritage Research at SFA ScholarWorks. It has been accepted for inclusion in Index of Texas Archaeology: Open Access Gray Literature from the Lone Star State by an authorized editor of SFA ScholarWorks. For more information, please contact cdsscholarworks@sfasu.edu. 
San Saba Mill Pond Park Survey, San Saba County, Texas

Creative Commons License

(c) $)(1)$ (9)

This work is licensed under a Creative Commons Attribution-NonCommercial 4.0 International License 
SAN SABA MILL POND PARK SURVEY, SAN SABA COUNTY, TEXAS

I. Waynne Cox

Texas Antiquities Committee Permit No. 1238

Center for Archaeological Research

The University of Texas at San Antonio ${ }^{\left({ }^{(B)}\right.}$

Archaeological Survey Report, No. 220

1993 
The following information is provided in accordance with General Rules of Practice and Procedure Chapter 41.11 (Investigation Reports), Texas Antiquities Committee:

1. Type of investigation: archaeological survey and research at San Saba Pond Park, San Saba, Texas;

2. Project name: San Saba Mill Pond Park;

3. County: San Saba County, Texas;

4. Principal investigator: Jack D. Eaton;

5. Name and location of sponsoring agency: L. K. Travis \& Associates, Inc., 1222 N. Main Ave., Suite 1010, San Antonio, Texas;

6. Texas Antiquities Committee Permit No. 1238;

7. Published by The Center for Archaeological Research, The University of Texas at San Antonio, San Antonio, Texas 78285-0658, 1993. 


\begin{abstract}
The Center for Archaeological Research, The University of Texas at San Antonio, was contracted by L. K. Travis \& Associates, Inc., to perform an archival research and field survey of 60 acres under consideration for the expansion of the Mill Pond Park within the City of San Saba. The research and survey were conducted by Research Associate Waynne Cox on April 21, 22 and 23. No evidence of either prehistoric or historic occupation was located within the survey area; however, archival research revealed further information concerning the nature and age of the mill for which the park was named. No further work is recommended on the area designated for expansion, but the nature of the park appears worthy of further research and development.
\end{abstract}


TABLE OF CONTENTS

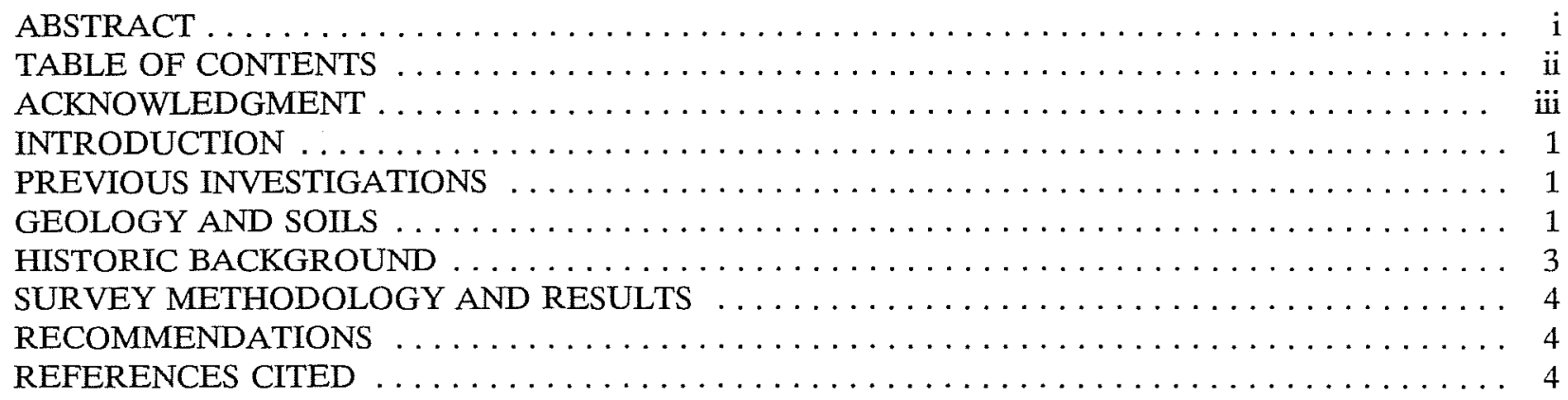

\section{LIST OF FIGURES}

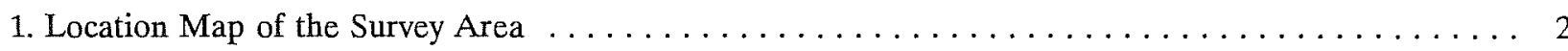




\section{ACKNOWLEDGMENTS}

The author will like to take this opportunity to express his appreciation for the assistance rendered by the San Saba City Manager, Darrin Barker, and his excellent staff. The City Surveyor, George Amthor III, also contributed valuable information that facilitated both the archival and field work. Finally, my thanks to L. K. Travis for allowing me to become involved in this interesting project. 



\section{INTRODUCTION}

In October of 1992, the Center for Archaeological Research (CAR) at The University of Texas at San Antonio (UTSA) was contacted by Larry K. Travis of $\mathrm{L}$. K. Travis \& Associates with a request to submit a proposal to provide archival research and a field survey of a 60 acre tract to be incorporated into the existing Mill Pond Park of the City of San Saba. A proposal was submitted at that time by Jack D. Eaton, Acting Director of the CAR. In April of 1993 the proposal was approval by the City of San Saba and L. K. Travis \& Associates, Inc., requested action on the project be accomplished as soon as possible. Center Research Associate Waynne Cox arrived in San Saba on April 21 and began research on the site. The survey and research was completed on April 24. The purpose of the study was to ascertain if any cultural resources would be impacted by the proposed development. Texas Antiquities Committee Permit No. 1238 was issued for the project.

Mill Pond Park is located immediately to the east of the city of San Saba on Mill Creek, an artisan spring-fed natural water course which has been dammed to form an attractive three and one-quarter acre lake (Fig. 1). The area contains a County Historical Museum, sports and recreational facilities, Recreational Vehicle parking, public swimming pool, and picnic facilities. The former mill structure has been replaced by a reconstructed building contributed and utilized by the San Saba Garden Club. The area below the dam and near the mill has been extensively landscaped with annuals and native vegetation.

The property to be developed as future parkland consists of two parcels. The larger area is located immediately adjacent to the south and contains slightly over 40 acres; while the smaller parcel, a triangular piece of under four acres, is to the east beyond a remote portion of the park recently used for landscape landfill.

\section{PREVIOUS INVESTIGATIONS}

There are four registered prehistoric sites located within approximately two miles of the survey area. All are located to the east along the terraces or previous channels of the San Saba River. Complete data was not available on three of the most recently identified sites, 41 SS 62,41 SS 63 , or 41 SS 65 , but complete site information for 41 SS 28 was provided by the Texas Archeological Research Laboratory (TARL). The site was identified in 1982 to be an extensive prehistoric occupation area along the upper terrace of an extinguished branch of the river. Although no datable artifact was recovered, the site appears to date to the archaic or possibly late prehistoric periods.

\section{GEOLOGY AND SOILS}

San Saba County is located in Central Texas and receives an annual average rainfall of 27 inches, and enjoys an average temperature of 67.2 degrees. The county contains 718,080 acres (1,122 square miles) primarily dedicated to stock raising and agricultural production, terming itself the "pecan capital of the world". The lands of the larger portion of the survey, the forty acres to the south, are composed of the Roughcreek-Eckrant types. These consist of very shallow and stony soils of approximately four to fourteen inches thick over limestone bedrock. Of this thin soil the upper half is generally moderately alkaline, dark grayish brown clay shading into dark brown stony clay above the bedrock. There are numerous outcrops of limestone ledges throughout this gently sloping hillside. These outcrops consist of weathered gray cobbles and boulders of coarsely fractured dolamite limestone. This environment gradually transitions into the Frio silty clay loams of the creek valley of the park. This soil type averages about forty-two inches in depth, under which is encountered a brown silty clay loam with occasional masses of calcium carbonate. The small portion of the survey, on the eastern margin, is composed of this type (Bynum 1982:26,40-41). 


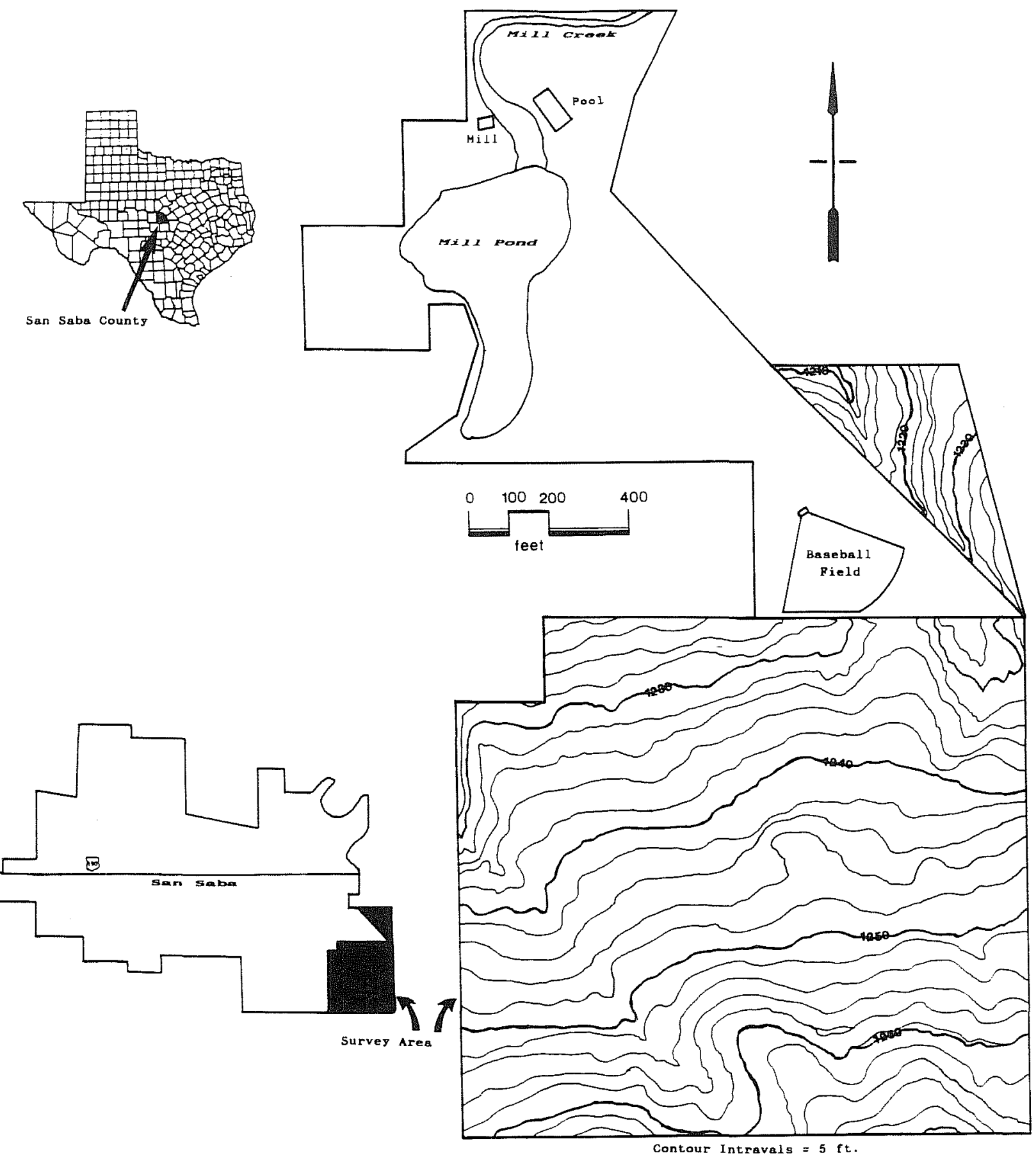

Figure 1. Location Map of the Survey Area. 


\section{HISTORIC BACKGROUND}

San Saba County was formed from a portion of what was once Bexar County on February 1, 1856. The first county election was conducted May 3, and among the elected officials was John Humphrey Brown, commissioner. A special election on July 19 approved the selection of a tract of ninety-three acres of donated land as the county seat. The parcel was a portion of Survey 38 which had been selected by Joseph Porter Brown, as the location of the Patent acquired from Ozwin Wilcox. His administrator, Dr. David Franklin Brown, auctioned the property in Bastrop County where it was acquired by Robert Daugherty McAnelly. McAnelly added an additional seven acres from his own bounty, Survey 37, adjacent to the tract on October 7, 1856. The resultant one hundred acres was then deeded to the chief justice and commissioners of San Saba County to establish the new town of San Saba (Upchurch 1946:98-100, SSCDR C:397). However, in the original grant for the town tract he stipulated "...reserving to myself exclusive control of the spring and waters of McAnelly Creek for the purpose of machinery after giving the town access to the spring and waters of said creek for all ordinary purposes" (SSCDR C:397). This would seem to indicate that he was operating machinery, or at least contemplated the use of such, at the time of the grant.

R. D. McAnelly had also been awarded an addition bounty grant of 640 acres, Survey 36, for his service in the "battle of San Antonio" (SSCDR D:234). From that tract he conveyed the portion..."South $4^{\circ}$ East 1285 varas (3568 $1 / 2$ feet) to the southeast corner of said survey to a stone mound...Thence South $45^{\circ}$ West 682 varas (1894 $1 / 3 \mathrm{feet}$ ) to a stone mound in the southeast line of the survey; Thence North $20^{\circ}$ West 1588 varas (4411 feet) to a stake on the bank of the river (San Saba)...Thence down the river, with its meanders South $77^{\circ}$ East 190 varas (527 $3 / 4$ feet) to place of beginning" to John H. Brown in October of 1862 (SSCDR B1:411). Four years later he sold Brown the adjoining property on McAnelly Creek "which I have heretofore possessed and which until now I reserved in all conveyances of land on said McAnallys (sic) Creek for the purposes of erecting machinery, said tract of land containing 500 acres, more or less." (SSCDR B3:118). This tract, the bulk of Survey 36 , contained both the property now designated as the county park and the area of the present survey proposed for future development.

John Humphrey Brown, "Shorty", was born January 1, 1818 and come to Texas in 1847. After contributing to the founding of the county, he helped organize the First Baptist Church and assisted in constructing the first log hut to serve as its place of worship. In order to deal with the problems the settlement was having with hostile Indians, a Home Guard was organized and "Shorty" served as the first Captain. In July of 1869, he served as the head drover on a cattle drive across West Texas to the Gila River in Arizona, returning in September of that same year (Jones 1983:42). It is reputed that he constructed the mill in 1867, and in view of the stipulations stated in the deed to the property, this is entirely plausible, although other histories of the county state that the mill was not constructed until 1874. However, deed transfers clearly establish that prior to 1871 he was operating the mill in partnership with J. S. Williams and James C. Rogan, both of whom were also original founders of the community (SSCDR F:81, Hamrick 1969:37). Brown died November 27, 1896 and was buried in the cemetery he had established on the road to Lampasas just to the east of the creek (Jones 1983:42).

The property containing the mill passed from his heirs to his partner, J. S. Williams, and in 1904 his widow, Mary, sold the tract to John Graves (SSCDR 42:525). The property then passed to T. M. Gray, Mrs. M. A. Flood, H. C. Galloway and John and L. M. Adams (SSCDR 43:409, 54:79, 61:564). In October of 1923 the property was acquired by T. A. Murry and S. E. W. Hudson, who organized and established the San Saba Water Company utilizing the waters of the mill pond (SSCDR 83:616). The property was later conveyed to San Saba County when it was established as a county park. A portion remaining of the mill building was utilized to construct the structure now serving the San Saba Garden Club. 


\section{SURVEY METHODOLOGY AND RESULTS}

The survey was begun on the larger tract to the south of the present park. Access was secured by permission of the City Manager's Office through a locked gate by a key granted to the author for the duration of his survey. Once on the land the parcel was inspected by transects from north to south or east to west as was deemed most efficient by the particular patterns of brush coverage. The northern half was generally covered by broken patches of scrub mesquite (Prosopis juliflora) and juniper (Juniperus ashii), with occasional fairly heavy infestation of cacti (Opuntia sp. and Echinocereus sp.). Shovel tests were attempted when warranted, but were essentially ineffective due to the shallow soils. Most of the area was densely covered by fractured limestone cobbles in many areas. The portion of the area toward the south was even more densely covered with brush and conditions were such that it was totally impractical to survey the extreme southeast corner. There was no evidence that any prehistoric occupation sites ever existed within the area, and survey results and archival research gave no indication of any historical structures or artifacts. The small tract on the eastern edge of the existing park was surveyed in the same manner. The soils in that area had greater depth, but several shovel tests failed to reveal any evidence of occupation.

\section{RECOMMENDATIONS}

Due to the lack of any evidence of prehistoric or historic occupation, no further archaeological work is recommended during the present expansion of the park facilities. However, the archival evidence indicates that the mill complex within the present park and the adjacent area possesses a great potential for future investigation. Deed records give indications that the area also once contained a two-story cotton gin and several homes. It appears that the mill channel could be traced and additional information on the colorful history of the operation could be developed. This information would be invaluable in determining the full potential of the site as an historical relic and could yield valuable information of the actual purpose and operation of the facility. If future development of the site is anticipated consideration should be given to limited archaeological testing to determine the amount of structural evidence that still remains. This park, if fully developed could become a unique example of an extremely early milling operation within the central portion of the State. Traditionally, the local mill served not only as an industrial complex, but also as a social center and for families venturing into town to have their agricultural produce processed and meet with their neighbors. The park now serves as an important part of the community and further development could only enhance its value to the community as well as to other citizens of the state.

\section{REFERENCES CITED}

Bynum, O. W.

1982 Soil Survey of San Saba County, Texas. United States Department of Agriculture, Soil Conservation Service, in cooperation with Texas Agricultural Experimental Station.

Hamrick, A. W.

1969 The Call of The San Saba: A History of San Saba County. San Felipe Press, Jenkins Publishing Company, Austin, Texas. 
Jones, D.

1983 San Saba County History 1856 -1983. San Saba County Historical Commission, San Saba County, Texas.

San Saba County Deed Records $(S S C D R)$

County Clerk's Office, County Courthouse, San Saba, Texas.

Texas Archeological Research Laboratory, Balcones Research Center (TARL)

1993 "Letter from Jean L. Hughes, May 22". TARL, College of Liberal Arts, The University of Texas at Austin, Austin, Texas. Letter on file, CAR-UTSA.

Upchurch, A. G.

1946 "A Sketch History of San Saba County, Texas". Southwestern Historical Quarterly, Volume L, No. 1, July 1946, Austin, Texas. 
